\title{
Assessment of fire emission inventories during the South American Biomass Burning Analysis (SAMBBA) experiment
}

\author{
Gabriel Pereira $^{1}$, Ricardo Siqueira ${ }^{2}$, Nilton E. Rosário ${ }^{3}$, Karla L. Longo ${ }^{2, a}$, Saulo R. Freitas ${ }^{2, a}$, Francielle S. Cardozo ${ }^{1}$, \\ Johannes W. Kaiser ${ }^{4}$, and Martin J. Wooster ${ }^{5,6}$ \\ ${ }^{1}$ Department of Geoscience, Federal University of Sao Joao del-Rei (UFSJ), Sao Joao del-Rei, Brazil \\ ${ }^{2}$ Center for Weather Forecast and Climate Studies, National Institute for Space Research (INPE), Cachoeira Paulista, Brazil \\ ${ }^{3}$ Environmental Sciences Department, São Paulo Federal University (UNIFESP), Diadema, São Paulo, Brazil \\ ${ }^{4}$ Max Planck Institute for Chemistry (MPIC), Mainz, Germany \\ ${ }^{5}$ Department of Geography, King's College London (KCL), London, UK \\ ${ }^{6}$ NERC National Centre for Earth Observation (NCEO), Leicester, UK \\ ${ }^{a}$ now at: Global Modeling and Assimilation Office, NASA Goddard Space Flight Center and USRA/GESTAR, \\ Greenbelt, MD, USA
}

Correspondence to: Gabriel Pereira (pereira@ufsj.edu.br)

Received: 26 December 2015 - Published in Atmos. Chem. Phys. Discuss.: 19 January 2016

Revised: 5 May 2016 - Accepted: 23 May 2016 - Published: 7 June 2016

\begin{abstract}
Fires associated with land use and land cover changes release large amounts of aerosols and trace gases into the atmosphere. Although several inventories of biomass burning emissions cover Brazil, there are still considerable uncertainties and differences among them. While most fire emission inventories utilize the parameters of burned area, vegetation fuel load, emission factors, and other parameters to estimate the biomass burned and its associated emissions, several more recent inventories apply an alternative method based on fire radiative power (FRP) observations to estimate the amount of biomass burned and the corresponding emissions of trace gases and aerosols. The Brazilian Biomass Burning Emission Model (3BEM) and the Fire Inventory from NCAR (FINN) are examples of the first, while the Brazilian Biomass Burning Emission Model with FRP assimilation (3BEM_FRP) and the Global Fire Assimilation System (GFAS) are examples of the latter. These four biomass burning emission inventories were used during the South American Biomass Burning Analysis (SAMBBA) field campaign. This paper analyzes and inter-compared them, focusing on eight regions in Brazil and the time period of 1 September-31 October 2012. Aerosol optical thickness $\left(\mathrm{AOT}_{550 \mathrm{~nm}}\right)$ derived from measurements made by the Moderate Resolution Imaging Spectroradiometer (MODIS) operating on board the Terra and Aqua satellites is also applied to
\end{abstract}

assess the inventories' consistency. The daily area-averaged pyrogenic carbon monoxide (CO) emission estimates exhibit significant linear correlations $(r, p>0.05$ level, Student $t$ test) between 3BEM and FINN and between 3BEM_FRP and GFAS, with values of 0.86 and 0.85 , respectively. These results indicate that emission estimates in this region derived via similar methods tend to agree with one other. However, they differ more from the estimates derived via the alternative approach. The evaluation of MODIS AOT $550 \mathrm{~nm}$ indicates that model simulation driven by 3BEM and FINN typically underestimate the smoke particle loading in the eastern region of Amazon forest, while 3BEM_FRP estimations to the area tend to overestimate fire emissions. The daily regional $\mathrm{CO}$ emission fluxes from 3BEM and FINN have linear correlation coefficients of $0.75-0.92$, with typically $20-30 \%$ higher emission fluxes in FINN. The daily regional $\mathrm{CO}$ emission fluxes from 3BEM_FRP and GFAS show linear correlation coefficients between 0.82 and 0.90 , with a particularly strong correlation near the arc of deforestation in the Amazon rainforest. In this region, GFAS has a tendency to present higher CO emissions than 3BEM_FRP, while 3BEM_FRP yields more emissions in the area of soybean expansion east of the Amazon forest. Atmospheric aerosol optical thickness is simulated by using the emission inventories with two operational atmospheric chemistry transport models: the 
IFS from Monitoring Atmospheric Composition and Climate (MACC) and the Coupled Aerosol and Tracer Transport model to the Brazilian developments on the Regional Atmospheric Modelling System (CCATT-BRAMS). Evaluation against MODIS observations shows a good representation of the general patterns of the $\mathrm{AOT}_{550 \mathrm{~nm}}$ time series. However, the aerosol emissions from fires with particularly high biomass consumption still lead to an underestimation of the atmospheric aerosol load in both models.

\section{Introduction}

Biomass burning is a global phenomenon and an ancient practice of human occupation, as well as a natural process. It consumes large amounts of vegetation across wide areas and modifies Earth surface characteristics. Fires still play a key role in ecosystem services, opening areas for livestock, agriculture, and pest control (Shimabukuro et al., 2013). In the last 5 decades, biomass burning has been extensively and persistently used all over the tropics for these purposes and has been involved in widespread deforestation and forest degradation (Crutzen and Andreae, 1990; Bustamante et al., 2016). Biomass burning emissions inject a considerable amount of oxidants and aerosols into the atmosphere, modifying atmospheric composition and reactivity and therefore disturbing the regional climate, water, and biogeochemical cycles (Andreae et al., 2004; Bowman et al., 2009). Moreover, fire emissions in tropical areas are not only felt regionally but also rapidly and strongly affect the global scale due to the efficiency of the atmospheric transport processes of trace gases and aerosols emitted and the high heat release, which reinforced the intense tropical convective activity (Kaufman et al., 1995; Val Martin et al., 2010). Extensive fire activity also disturbs the environmental system, producing soil depletion, damaging flora and fauna, decreasing biodiversity, and even affecting human life (Fearnside, 2000).

An accurate temporal and spatial estimate of biomass burning emissions is critical to a reliable analysis of the associated effects. Nowadays, efforts to quantify emissions from biomass burning from space-borne instruments have increased considerably in scope, but uncertainties in the input data and within the different methodologies can still lead to errors of up to an order of magnitude for trace gases and aerosol emission totals (Vermote et al., 2009; Baldassarre et al., 2015).

Several products of burned area (BA) and fire emission inventories, such as the Global Fire Emissions Database (GFED; van der Werf et al., 2010), the Brazilian Biomass Burning Emission Model (3BEM; Longo et al., 2010), the Global Fire Assimilation System (GFAS; Kaiser et al., 2009, 2012), and the Fire INventory from NCAR (FINN; Wiedinmyer et al., 2011) have been published. Most of the fire emission inventories utilize active fire locations and burned area to estimate the trace gases and aerosol emissions released into the atmosphere (Mao et al., 2014). However, the temporal and spatial distribution of biomass burning emissions is affected by several sources of errors related, e.g., to the lack of detection of small fires during prescribed and agricultural burning. Also, global burned area products are unsuitable to estimate the burned area of small fires due to the limitations of their algorithms (Giglio et al., 2006, 2010; Randerson et al., 2012).

Most methodologies to estimate biomass burning emissions utilize the relationship proposed by Seiler and Crutzen (1980), which we will call the "BA-based approach":

$M^{[\epsilon]}=A B \beta \mathrm{EF}^{[\epsilon]}$,

where $M^{[\in]}$ is the emission load of species $\in(\mathrm{g}), A$ is the burned area (in $\left.\mathrm{km}^{2}\right), B$ is the fuel load $\left(\mathrm{kg} \mathrm{km}^{-2}\right), \beta$ is the combustion completeness (unitless), and $\mathrm{EF}^{[\in]}$ is the emission factor released species $\in\left(\mathrm{g} \mathrm{kg}^{-1}\right)$. In this method, the burned area is one of the parameters necessary to estimate the emission of trace gases and aerosols, usually estimated by Earth Observation (EO) satellites; typically, since fires must have already occurred to produce a burned area, this is not that well suited to providing near-real-time air quality forecasts in models that include vegetation fires. Other factors in Eq. (1) can also be difficult to determine; for example, the combustion completeness typically depends on the moisture present in the biomass (and thus in part on micrometeorology), and the fuel load (average biomass and its fraction above ground) is hardly homogeneous (Chuvieco et al., 2004; Yebra et al., 2009; De Santis et al., 2010).

In the last decade, the development of sensors more targeted at active fire observations has allowed the estimation of the radiative energy flux released by fires or the fire radiative power (FRP, in $\mathrm{J} \mathrm{s}^{-1}$ ). The FRP accuracy has been evaluated by Kaufman et al. (1998) and Wooster et al. (2003), showing an average error of 16 and $6.5 \%$, respectively. However, the error could be largely due to the spatial resolution of several sensors; basically, the atmospheric transmittance and the cloud obscuration can cause an omission error of 15 and $11 \%$ in FRP estimates, respectively (Schroeder et al., 2008). Also, according to Vermote et al. (2009), the integration of FRP over the fire cycle and its conversion to burned biomass can cause an error of 21 and 10-30\%, respectively, varying according to heterogeneity of regional/zonal characteristics.

Continuous acquisition of FRP over a fire's lifetime provides the fire radiative energy (FRE, in MJ) released by the fire process. New fire emission methods utilize the FRE to calculate the amount of biomass burned and/or the emission of trace gases and aerosols (Wooster et al., 2005; Ichoku and Kaufman, 2005; Ellicot et al., 2009; Freeborn et al., 2011; Kumar et al., 2011): 
$\operatorname{FRE}_{\text {grid }_{(\text {long,lat) }}}=\frac{1}{2} \sum_{i=1}^{n}\left(\mathrm{FRP}_{n}+\mathrm{FRP}_{n+1}\right) \cdot\left(T_{n+1}-T_{n}\right)$,

$M^{[\epsilon]}=\operatorname{FRE}_{\text {grid }_{(\text {long,lat) }}} \gamma \mathrm{EF}^{[\in]}$,

where $\mathrm{FRE}_{\text {grid }_{\text {(lon.lat) }}}$ provides radiative energy at a geographical location in terms of longitude and latitude of a specific centered point of a regular grid; $T$ is the time sequence of FRP acquisitions; $n$ represents the $n$th sample; and $\gamma$ is the FRP-biomass conversion factor $\left(\mathrm{kg} \mathrm{MJ}^{-1}\right.$; Wooster et al., 2005; Kaiser et al., 2012). In this method, parameters such as fuel load, burning efficiency, and the presence of moisture in the soil and in vegetation directly influence the observed energy radiated by the fires and do not have to be separately considered.

The South American Biomass Burning Analysis (SAMBBA) was an airborne experiment design to characterize the smoke physical and chemical properties in Amazonian rainforest and central area of Brazil. The SAMBBA campaign took place in September 2012. The operational smoke forecasting system built to support SAMBBA flight planning utilized four fire emission inventories, which deployed the aforementioned approaches: (i) 3BEM (Longo et al., 2010), (ii) Brazilian Biomass Burning Emission Model with FRP assimilation (3BEM_FRP; Pereira et al., 2009), (iii) GFAS (Kaiser et al., 2012), and (iv) FINN (Wiedinmyer et al., 2011). This study provides an intercomparison and evaluation of these inventories, with focus on the SAMBBA field campaign experiment.

\section{Data and methodology}

\subsection{Inventories description}

\subsubsection{Brazilian biomass burning emission models (3BEM and 3BEM_FRP)}

3BEM is a model developed to estimate the daily fire emissions based on the location of actively burning fire "hotspots" (i.e., areas of combustion detected using active fire/thermal anomaly detection algorithms) derived via orbital remote sensing. 3BEM utilizes the Wildfire Automated Biomass Burning Algorithm (WF_ABBA) applied in the Geostationary Operational Environmental Satellite (GOES) constellation data (Prins et al., 1998); the MOD14 and MYD14 products of the Moderate Resolution Imaging Spectroradiometer (MODIS) aboard the Terra and Aqua satellites (Justice et al., 2002); and the fire product developed by the Environmental Satellite Division (DSA) of National Institute for Space Research (INPE), which uses the Spinning Enhanced Visible and Infrared Imager (SEVIRI) on board Meteosat Second Generation, GOES, MODIS, and Advanced Very High Resolution Radiometer (AVHRR) on board the
National Oceanic and Atmospheric Administration (NOAA) constellation (Setzer et al., 1994).

The 3BEM version initially developed by Longo et al. (2010) estimates the emitted mass of trace gases and aerosols related to each fire detected by remote sensing as described in Eq. (1). Therefore, the locations of the detected fire hotspots are cross-tabulated with MODIS Land Cover map to allow the estimation of aboveground biomass density, combustion factor, and emission factor from literature values (Olson et al., 2000; Andreae and Merlet, 2001; Houghton et al., 2001; Sestini et al., 2003; Akagi et al., 2011). Also, the model filters all fires located in a $1 \mathrm{~km}$ radius to prevent double counting between fire products.

The updated 3BEM includes FRP assimilation (3BEM_FRP; Pereira et al., 2009) and utilizes the algorithm of the earlier 3BEM version but with burned biomass directly estimated using FRE estimates, as described in Eq. (3). The 3BEM_FRP model groups all FRP values estimated by MODIS, GOES, and METEOSAT products according to their time acquisition, eliminating the low confidence fire pixels (values below $50 \%$ for MOD14, MYD14, and METEOSAT products, and flags 4 and 5 for WFABBA/GOES product) and minimizing the impact of the MODIS bow-tie effect as described in Freeborn et al. (2011). Also, due to the high frequency of observations (mainly in GOES and SEVIRI data) 3BEM needs only one fire detection to estimate the biomass burned and its associated emissions due to the filtering process (Longo et al., 2010). If the active fire has no subsequent observations in the next $4 \mathrm{~h}$, the algorithm assumes that the fire event is over. Thus, missed detections due to cloud cover have an impact on the FRE integration if the cloud persists for more than eight satellite acquisitions.

Some of these FRP estimates are compromised by sensor saturation over larger fires, particularly GOES over South America (Xu et al., 2010). Thus, to not ignore important episodes of biomass burning by removing GOES saturated pixels, for which FRP values are not provided, 3BEM_FRP utilizes Eq. (4) to estimate the energy released by fires, based on the premise that emitted spectral radiance $\left(M_{\lambda}\right)$ in spectral band centered at $3.9 \mu \mathrm{m}$ is proportional to FRP (Wooster et al., 2003).

$\mathrm{FRP}_{\mathrm{MIR}}=\frac{A_{\mathrm{g}}}{a} \sigma \int_{3.76}^{4.03} M(\lambda, T) \mathrm{d} \lambda-M_{b}$,

where $A_{\mathrm{g}}$ represents the area of the GOES pixel $\left(\mathrm{km}^{2}\right) ; a$ is an empirical constant adapted for the GOES MIR spectral band ( $\mathrm{W} \mathrm{m}^{-2} \mathrm{sr}^{-1} \mu \mathrm{m}^{-1} \mathrm{~K}^{-4}$; Wooster et al., 2005); $\sigma$ is the Stefan-Boltzmann constant $\left(5.66 \times 10^{-8} \mathrm{~W} \mathrm{~m}^{-2} \mathrm{~K}^{-4}\right)$; $M$ is the Planck curve $\left(\mathrm{W} \mathrm{m}^{-2} \mu \mathrm{m}^{-1}\right) ; \lambda$ is the wavelength $(\mu \mathrm{m}) ; T$ represents the temperature $(\mathrm{K})$; and $M_{\mathrm{b}}$ is the radiance emitted by the background (110 MW). FRP values estimated by GOES satellites below $1000 \mathrm{MW}$ are corrected by 
$+17 \%$ and FRP values higher than $1000 \mathrm{MW}$ are corrected by $+41 \%$ (Xu et al., 2010). This procedure is also applied to SEVIRI data but, due to its spatial coverage, we decided not to include these data in the present analysis. Pereira et al. (2009) describe the 3BEM_FRP method in detail.

A clustering process performs the combination of all detected fires from different sensors. In this step, the size of a matrix that merges FRP data can be defined according to the spatial resolution and grid configuration of the atmospheric model. Consequently, the convolution mask $\eta(\gamma, \kappa)$ of size $M \times N$ (rows $\times$ columns), running over the grid with FRP areal density $\left(\mathrm{FRP}_{\mathrm{ad}}\right.$, in $\mathrm{W} \mathrm{m}^{-2}$; defined by weighting the FRP values by pixel area) values estimated by different satellites $\xi$ (long,lat), will result in the grid (FRP grid) containing all clustered fires for a given time step.

$\mathrm{FRP}_{\text {grid }_{(\text {lon, lat }, t)}}=\sum_{\gamma=-\alpha}^{\alpha} \sum_{\kappa=-\beta}^{\beta} \eta(\gamma, \kappa) \xi($ long $+\gamma$, lat $+\kappa, t)$,

where the clustered grid is defined to all points where the mask of $M \times N$ size overlaps the image completely (lon $\epsilon[\alpha, M-\alpha]$, lat $\epsilon[\beta, N-\beta]$ ). Moreover, if the interval between two acquisitions is greater than $4 \mathrm{~h}(\Delta T>14400 \mathrm{~s})$ at any time step of the FRP integration, the observations are assumed to originate from two or more independent fires.

\subsubsection{GFAS}

The GFAS is an approach used to map daily global fire emission through FRP observations. Therefore, GFAS also assumes that the electromagnetic radiation emitted by fires is related to the consumption of burned biomass (Wooster et al., 2005). In the GFAS version (1.1) used in this study, FRP values of MOD14 and MYD14 fire products from Terra and Aqua satellites, respectively, are used to estimate the average of observed FRP areal density. GFAS estimates open vegetation fire trace gas and particulate emissions from each fire detected as described in Eq. (3).

The model performs a clustering process of observed FRP $\left(F_{i}\right)$, pixel area $\left(A_{i}\right)$, and view zenith angle $(\theta)$ to sensor pixels with valid observations (i) to estimate the $\mathrm{FRP}_{\mathrm{ad}}$. The clustering process also takes observations of $F_{i}=0$, i.e., nofire, into account. Thus, for each individual grid cell the estimated $\mathrm{FRP}_{\mathrm{ad}}$ could be calculated as

$\operatorname{FRP}_{\mathrm{ad}}=\frac{\sum_{k} \sum_{i_{k} \in j} F_{i_{k}} \cdot \cos ^{2}\left(\theta_{i_{k}}\right)}{\sum_{k} \sum_{i_{k} \epsilon j} A_{i_{k}} \cdot \cos ^{2}\left(\theta_{i_{k}}\right)}$,

where $i_{k}$ represents the pixel $i$ of satellite product $k$ (MOD14, MYD14). This formulation implicitly corrects the MODIS bow-tie effect and partial cloud/ice/snow/water cover of a grid cell. Observation gaps are subsequently filled with a data assimilation approach that currently assumes persistence of the fires.

In GFAS, the coefficient that converts the FRP ${ }_{a d}$ to dry matter combustion rate is based on eight land cover classes
Table 1. Land Use and Land Cover (LULC) classes based on Global Land Cover Characterization (GLCC).

\begin{tabular}{llll}
\hline 1 & Crop/mixed farming & 11 & Semi-desert \\
2 & Short grassland & 12 & Ice cap/glacier \\
3 & Evergreen needleleaf tree & 13 & Bog or marsh \\
4 & Deciduous needleleaf tree & 14 & Inland water \\
5 & Deciduous broadleaf tree & 15 & Ocean \\
6 & Evergreen broadleaf tree & 16 & Evergreen shrub \\
7 & Tall grass & 17 & Deciduous shrub \\
8 & Desert & 18 & Mixed woodland \\
9 & Tundra & 19 & Forest/field mosaic \\
10 & Irrigated crop & 20 & Water and land mixture \\
\hline
\end{tabular}

(cf. Heil et al., 2010, Kaiser et al., 2012). In addition, the emission load of 40 species is calculated using emission factors from Andreae and Merlet (2001), with subsequent updates from Christian et al. (2003). Kaiser et al. (2012) describe the inventories method in detail.

\subsubsection{FINN}

FINN is an approach to estimate daily fire emissions at $1 \mathrm{~km}$ resolution through satellite observation of active fires. The FINN model produces global estimates of aerosols and trace gases of open vegetation fires, as described in Eq. (1). The FINN utilizes the MOD14 and MYD14 fire products, processed by MODIS Rapid Response (MRR) or by the MODIS Data Processing System (MODAPS) Collection 5. However, since MODIS observations do not cover the entire globe daily, due to orbital gaps, FINN smears MODIS detections of active fire over 2 days. For each fire located in the equatorial region, it is assumed that the next day the fire will be half of its original size (Wiedinmyer et al., 2011).

Similarly to 3BEM, the FINN model removes multiple detections of same fire pixel prior to estimation of the trace gases and aerosols released. In addition, for each active fire, FINN estimates as $1 \mathrm{~km}^{2}$ the burned area for most of land use classes, with the exception of grasslands/savannas in which the burned area is assumed to be $0.75 \mathrm{~km}^{2}$. To estimate the emissions of trace gas and aerosol species, emission factors derived from Andreae and Merlet (2001) and Akagi et al. (2011) are used, as well as the MODIS Land Cover Type for 2005 and the MODIS Vegetation Continuous Fields (VCF) product. Wiedinmyer et al. (2011) describe the procedures adopted in detail.

\subsection{MODIS aerosol optical thickness (AOT)}

The aerosol optical depth (AOD) product from MODIS sensors aboard the Aqua and Terra satellites is used to provide a first order assessment of the impacts of the two distinct methods to estimate biomass burning emission: BAbased and FRP-based. In this work, the MODIS Level 2.0 Collection 5.1 (051) data and Level 3 atmospheric prod- 


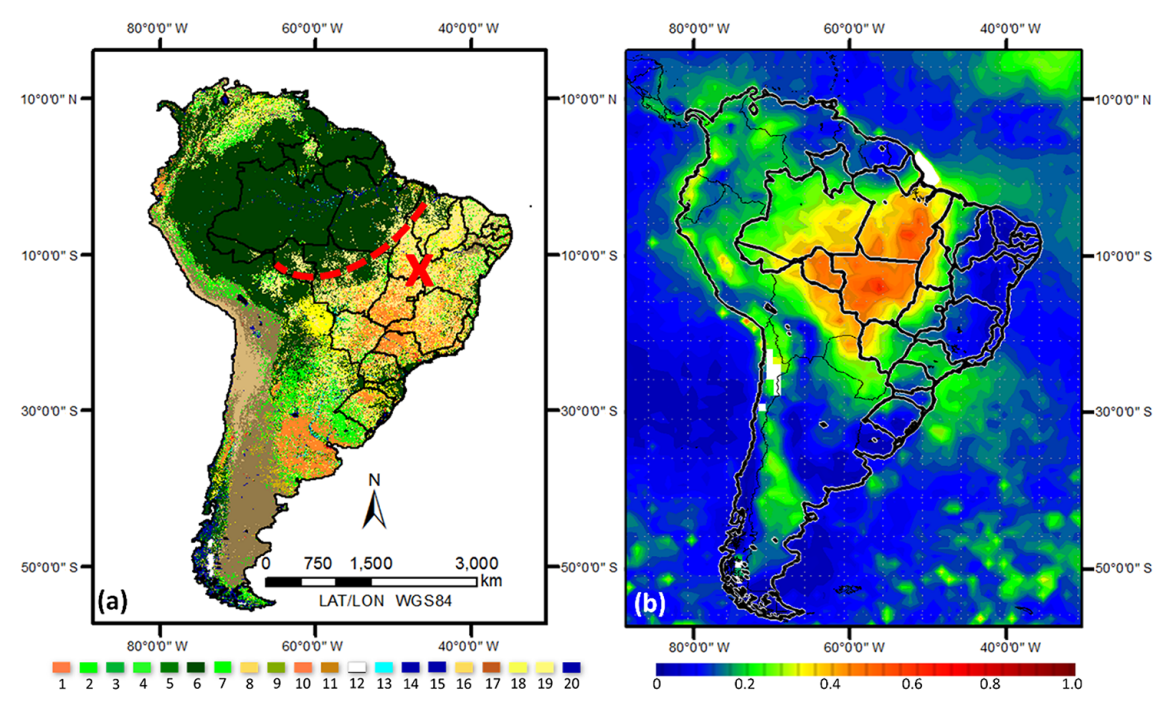

Figure 1. (a) MCD12 Land Use and Land Cover (LULC) for South America with the dotted red line representing the Amazonian Arc of Deforestation and soybean expansion in Brazilian Cerrado (marked as X); (b) time-averaged Aqua MODIS aerosol optical thickness at $550 \mathrm{~nm}$ during 1 September-31 October 2012 over South America.

uct denominated MYD08_D3 (mean aerosol optical thickness at $550 \mathrm{~nm}$, i.e., AOT $_{550 \mathrm{~nm}}$ ) are utilized to compare the fire emission inventories used during the SAMBBA campaign between 1 September and 31 October 2012. The MODIS daily global product merges all MODIS acquisitions over the globe on an equal-angle grid with $1^{\circ}$ resolution (Kaufman and Tanré, 1998). Figure 1a shows the MODIS MCD12 Land Use and Land Cover (LULC) product for South America with LULC classes described in Table 1. During the SAMBBA field campaign, the highest biomass burning aerosol loadings were observed over Brazilian territory, mainly over the southeastern edge of the Amazonian forest (dotted red line, known as Arc of Deforestation) and in the soybean expansion area in the Brazilian savannah (marked as $\mathrm{X}$ ), as shown in the time-averaged (1 September-31 October 2012) AOD $_{550} \mathrm{~nm}$ field, derived from MODIS sensor aboard Aqua satellite (Fig. 1b). The high values of AOD related to fires located in eastern Mato Grosso (mainly in the secondary forest) and in transition areas of Amazon rainforest and Brazilian savannah are noteworthy; soybean expansion areas, which present high concentration of fires, have a lower amount of biomass than Amazon rainforest and the strong ventilation favors the transport of smoke to west.

\subsection{Inventories configuration and analysis description}

To evaluate the fire emission inventories utilized during the SAMBBA experiment, we used the 3BEM preprocessor to generate the gridded data in geographical coordinates with a spatial resolution of $0.1^{\circ}$. The 3BEM preprocessor generates daily emission fluxes of several species, but in this work we selected only carbon monoxide (CO) emission fields from 1 September to 31 October 2012 to analyze. The four in- ventories are compared over eight sub-domains windows with sizes of $10^{\circ} \times 10^{\circ}$ that typically cover different Brazilian states (Fig. 2a) and different fire regimes and biomes (Fig. 2b).

Two models were selected for real-time applications during SAMBBA experiment: the Monitoring Atmospheric Composition and Climate (MACC) from European Centre for Medium-Range Weather Forecasts (ECMWF) with GFAS fire emission inventory (described in Sect. 2.1.2) and the Coupled Chemistry Aerosol and Tracer Transport model to the Brazilian developments on the Regional Atmospheric Modelling System (CCATT-BRAMS) with 3BEM fire emission inventory (described in Sect. 2.1.1). These models were selected due to their distinct methodologies for estimating the biomass burning emissions (the first a FRPbased approach, and the second the BA-based approach). The MACC/ECMWF model simulation had a global domain, about $0.8^{\circ}$ (T255) horizontal resolution, 60 levels vertical levels, and a forecast frequency of $6 \mathrm{~h}$. It assimilates MODIS AOD observations and the full set of meteorological observations that are used for the operational weather forecasts of ECMWF. The CCATT-BRAMS simulations were performed for the South America domain, $0.22^{\circ}$ of horizontal resolution, 24 levels of vertical resolution, forecast operation mode, forecast frequency of $3 \mathrm{~h}$, and boundary conditions from Center for Weather Forecasting and Climate Research (CPTEC) model. 


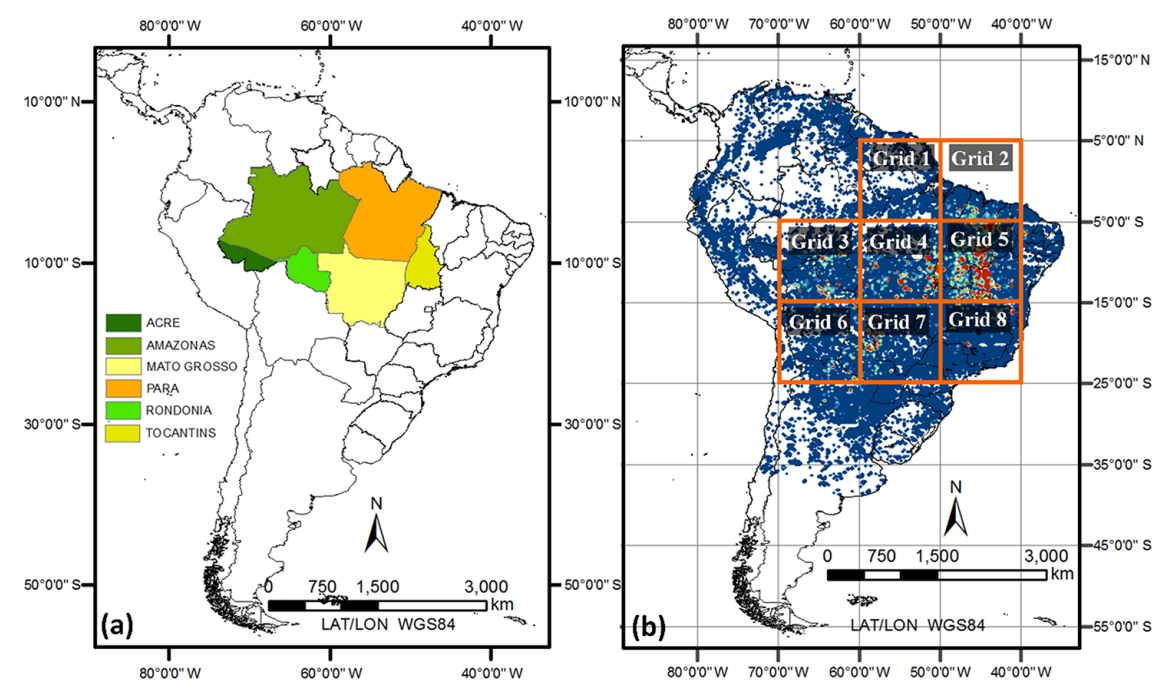

Figure 2. South America maps highlighting (a) the Brazilian states of Acre, Amazonas, Mato Grosso, Para, Rondonia, and Tocantins, where SAMBBA field campaign took place; and (b) the eight sub-domains windows for the biomass burning inventories comparison.

\section{Results and discussion}

\subsection{Comparing emission inventories spatially}

During the SAMBBA experiment, four inventories were used in near real time within atmospheric chemistry transport models to support the SAMBBA flight planning (FINN, GFAS, 3BEM, 3BEM_FRP). Each inventory's spatial distribution of total $\mathrm{CO}$ emission $\left(10^{4} \mathrm{~kg} \mathrm{~m}^{-2}\right)$ over South America, from 1 September to 31 October 2012, is depicted in Fig. 3, according to the respective methodologies used to estimate the emission loading.

The intercomparison shown in Fig. 3 demonstrates that inventories that utilize the same (i.e., FRP-based or BA-based) methodology show similar spatial patterns in $\mathrm{CO}$ emissions $\left(\mathrm{kg} \mathrm{m}^{-2}\right)$, not only in the Amazon basin but across all of South America, although they differ in their absolute values. The CO emissions estimated by the 3BEM and FINN emission inventories (Fig. 3a and b, respectively) present higher values than 3BEM_FRP (Fig. 3c) and GFAS (Fig. 3d) in the regions where the main processes of forest logging and subsequent agricultural expansion (grids 3, 4, and 5) occur. The highest emissions in 3BEM and FINN are located mainly in Rondonia State (grid 3) and in Mato Grosso State (grid 4), where most of the SAMBBA flights took place.

Cardozo et al. (2014) analyzed the fires pattern in Rondonia between 2000 and 2011 and identified that most fires result in relatively small "burn scars" on the landscape, with areas of 20 to 80 ha ( $64 \%$ of cases). In addition, only $6.5 \%$ of all burned areas in Rondonia are associated with recently deforested areas. This could indicate that 3BEM and FINN are overestimating the $\mathrm{CO}$ emission load due to an erroneous assumption that observed fires occur in forest instead of livestock and permanent crops, which have lower aboveground biomass. Furthermore, 3BEM_FRP and GFAS inventories do not display a similar pattern to 3BEM and FINN because their emissions are directly related to FRP, with a weaker dependency on land cover type. Thus, areas with low aboveground biomass will provide low values of FRE due the observed characteristics of the fire activity and thus low values of CO.

The spatial distribution of the emission inventories suggests that fires in the region are strongly related to deforestation activity and therefore to the general economy, with a strong trend in recent years of fires in secondary forests (Cardozo et al., 2014). In Fig. 3c, higher emission loads are located in the east of Brazil (grid 5), mainly in the Cerrado biome, a vegetal formation composed of savanna and other typically low-density vegetation formations, which include trees of $15 \mathrm{~m}$ height (as shown in Fig. 1a). This region is now economically used, constituting a new agricultural frontier of Brazil (with more than 100 million hectares suitable for modern mechanized crop agriculture, mainly soybean). In this area, the four fire inventories differ considerably. The inventories that use the FRP approach show much higher emission loads compared to 3BEM and FINN.

The difference in South American daily area-averaged emission of $\mathrm{CO}\left(\mathrm{kg} \mathrm{m}^{-2}\right)$ between 1 September and 31 October 2012 was quantified via linear correlation coefficient analysis (all significant at $p<0.05$ ) (Fig. 4). The highest linear correlation coefficients were found between 3BEM and FINN with 0.86 , between 3BEM_FRP and GFAS with 0.85 , and between GFAS and FINN with 0.84. These high linear correlations indicate that inventories produced using similar emission methods tend to agree with each other. The third correlation reflects that both inventories use the same active fire observations (MODIS), albeit with different data processing. We highlight that all were significant at $p>0.05$ 


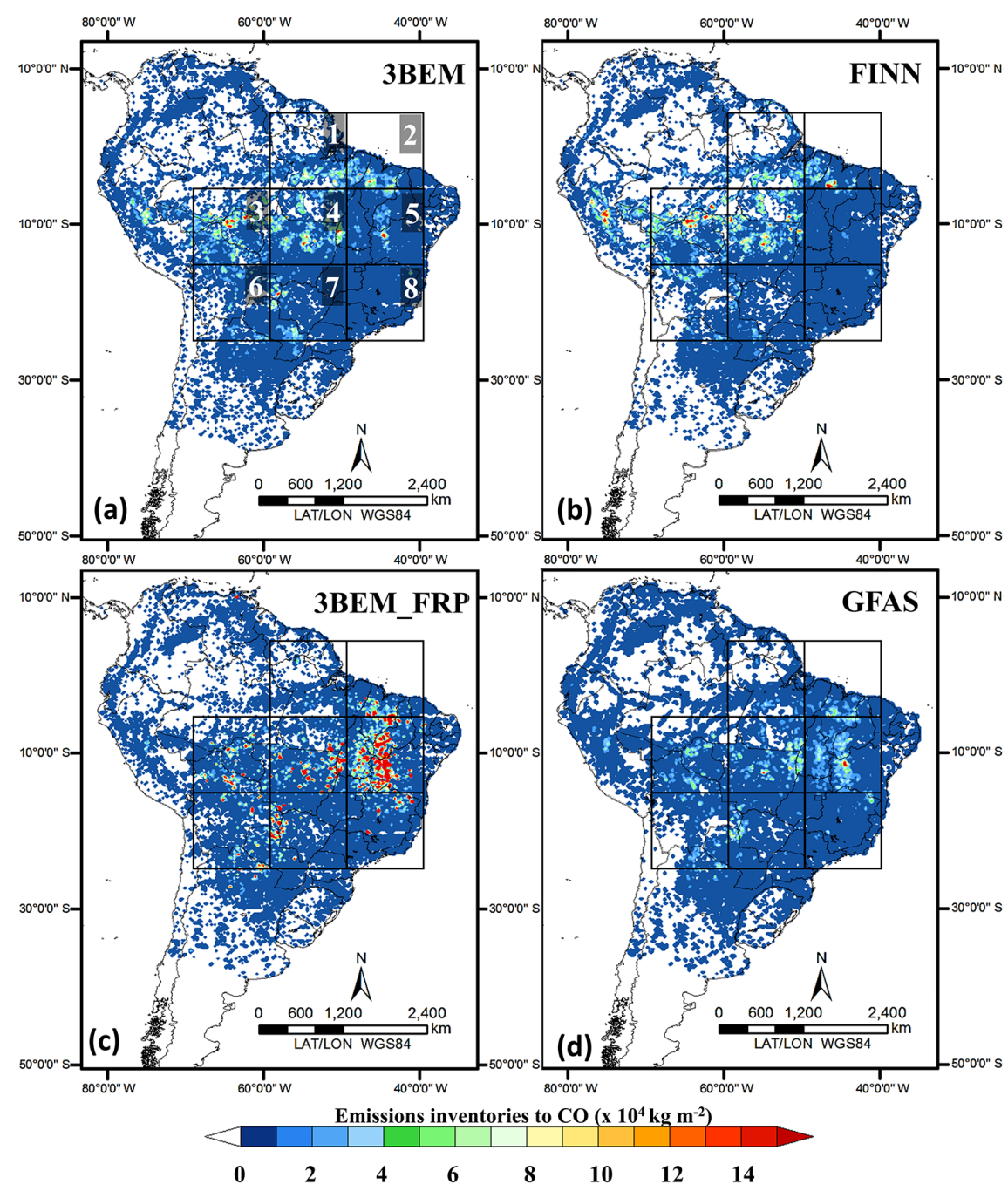

Figure 3. Spatial distribution of total CO emissions $\left(10^{4} \mathrm{~kg} \mathrm{~m}^{-2}\right)$ over South America from 1 September to 31 October 2012, estimated by (a) 3BEM, (b) FINN, (c) 3BEM_FRP, and (d) GFAS.

level, using the Student $t$ test. To analyze the measures of accuracy of regression between fire inventories we used the bootstrap technique (Efron, 1982). In this technique, a population of $1.0 \times 10^{4}$ reconstructs the regression and provides the parameters to create the confidence interval and error analysis of model estimation.

The bootstrap regression among the daily area-averaged $\mathrm{CO}$ values to $3 \mathrm{BEM}$ and FINN emission inventories present a linear correlation between 0.75 and 0.92 with a tendency of FINN to overestimate, relative to $3 \mathrm{BEM}$, the emission load of CO in $20-30 \%$ (Fig. 4). This apparent FINN overestimation is seen in the majority of grids, with the exception of grids 2, 5, and 7 (Fig. 5a). In areas where FINN emissions are lower than 3BEM emissions, vegetation is mainly composed of Brazilian Cerrado (grids 2 and 5), while the Brazilian Pantanal wetland biome (grid 7) is predominantly composed of savannah and grassland, with the additional presence of de- ciduous and semi-deciduous forest. Since 3BEM and FINN implement similar methodologies to estimate the emission load of species released by wildfires, the parameters used in Eq. (1), such as aboveground biomass, are likely to be associated with the relatively high estimation in $\mathrm{CO}$ values.

The intercomparison analysis of the daily area-averaged $\mathrm{CO}$ values to $3 \mathrm{BEM}$ and GFAS inventories shows a linear correlation coefficient between 0.75 and 0.85 with higher values over the Arc of Deforestation in the Amazon rainforest (Fig. 1a). However, GFAS has a tendency to present higher $\mathrm{CO}$ emissions (by 10-20\%) in grids 5 and 8 and to underestimate by $20-30 \%$ in grids 3 and 4 (Fig. 5b) when compared to 3BEM. In these areas, the vegetation is dominated by the Amazon biome, along with a small area of Cerrado (located in the south of the grids), with presence of evergreen broadleaf forest, tropical degraded forest, and cropland/livestock areas. Moreover, the daily area-averaged CO 

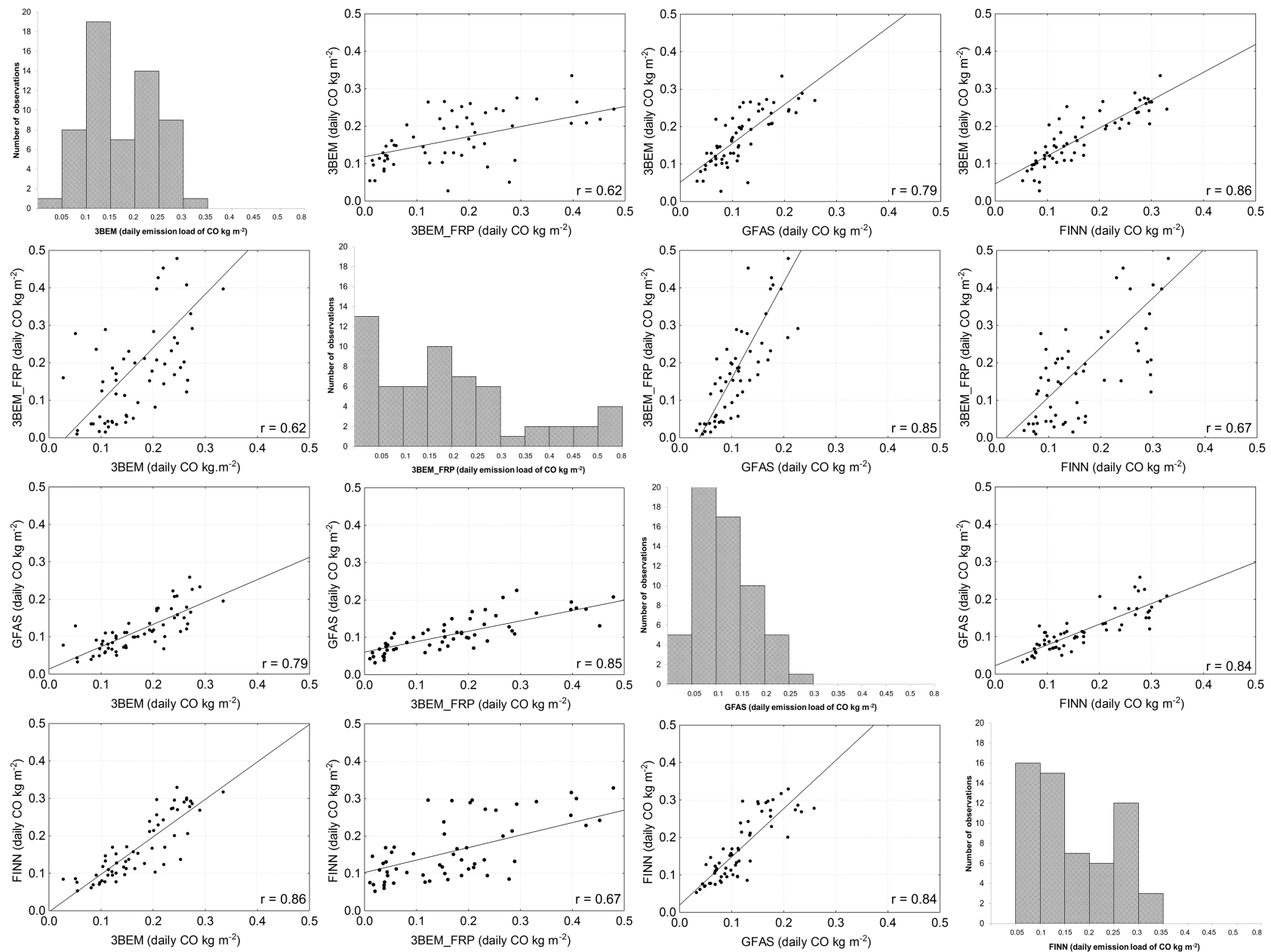

Figure 4. Linear regression between daily area-averaged emission load of CO to South America from 3BEM, 3BEM_FRP, FINN, and GFAS examined between 1 September and 31 October 2012. In the graph, $x$ and $y$ axis represent the $\mathrm{CO}\left(\mathrm{kg} \mathrm{m}^{-2}\right)$ of each fire inventory (i.e., the first line of 3BEM regressions; 3BEM_FRP, GFAS, and FINN are $x$ axis).

values estimated by GFAS present a considerable difference in the region of soybean expansion in grid 5.

Similar to GFAS, the relationship among the daily areaaveraged $\mathrm{CO}$ values to 3BEM and 3BEM_FRP shows a linear correlation coefficient between 0.65 and 0.75 . However, 3BEM_FRP has a tendency to overestimate the CO values by $60-85 \%$ in grid 5 and to underestimate by $10-15 \%$ in grids 3 and 4 (Fig. 5c). The 3BEM_FRP model presented an elevated emission of CO in grid 5, possibly due the GOES viewing zenith angle (high viewing angles results in erroneous values of infrared brightness and present a large pixel area,; Roberts et al., 2005; Vermote et al., 2009; Peterson et al., 2012). In addition, in grid 5, cloud absence may influence in the FRP cycle, leading to an overestimation due the large number of acquisitions in high view angles. The relationship between the daily area-averaged $\mathrm{CO}$ values to 3BEM_FRP and GFAS shows a linear correlation between 0.82 and 0.90 . Accordingly, the 3BEM_FRP model has a tendency to present higher emission fluxes of CO than GFAS, mainly in some areas of deforestation arc and in grid 5 that could reach $100 \%$ (Fig. 5d). The high values are associated with assimilation of GOES FRP in 3BEM_FRP, while GFAS utilizes only MODIS FRP data.

The fieldwork measurements acquired during the SAMBBA campaign indicate that the near-real-time air smoke forecasts based on BA-based inventories, such as 3BEM used by CCATT-BRAMS, typically underestimated smoke loading in the central to eastern region of the Amazon forest (near Mato Grosso and Tocantins States), as described in Rosário et al. (2013). In addition, the emission inventories tended to overestimate the smoke loading in the northwestern part of Rondonia (indicated in Fig. 2a). However, during the SAMBBA campaign lower values of $\mathrm{CO}$ emissions were identified, showing an overestimation of emission flux estimates in this region. In general, all fire emission inventories present a good agreement, with most regressions significant at $p>0.05$ level, according to the Student $t$ test (Table 2, non-significant regression marked in 


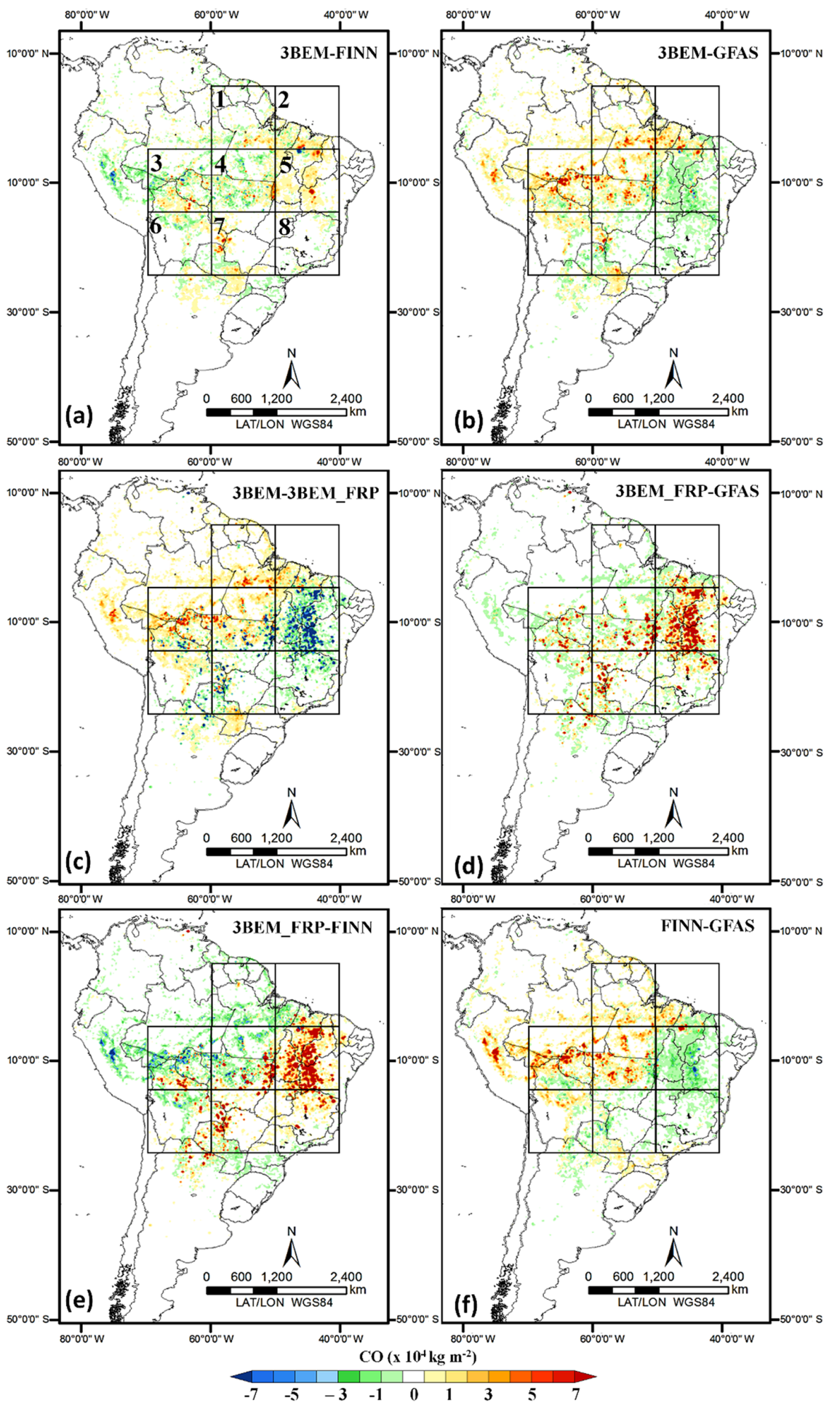

Figure 5. Difference between fire inventories. (a) 3BEM-FINN; (b) 3BEM-GFAS; (c) 3BEM-3BEM_FRP; (d) 3BEM_FRP-GFAS; (e) 3BEM_FRP-FINN; (f) FINN-GFAS.

red). The only regression that presented low values of linear correlation coefficients are located in grid 5 with values lower than 0.30. Moreover, regression between 3BEM and FINN presents the highest correlation in most of the grids.
Also, the absolute bias analysis indicate a high variability in daily area-averaged emission load of $\mathrm{CO}$ between the four fire inventories. 


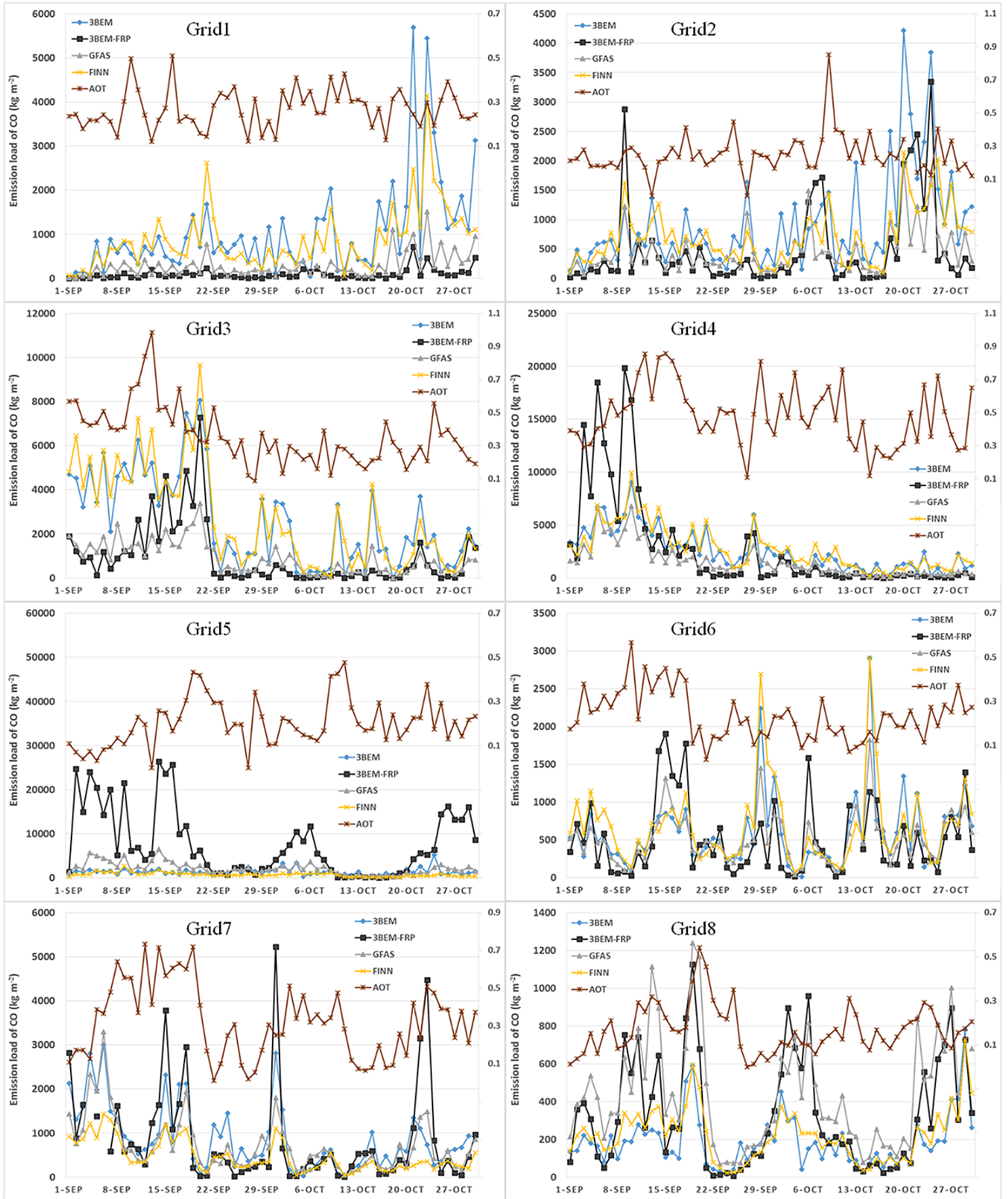

Figure 6. Lat-long average time series of Aqua MODIS AOT $550 \mathrm{~nm}$ and 3BEM, 3BEM_FRP, GFAS, and FINN emission load of CO time series. 
Table 2. Linear correlation coefficients $(r)$ between 3BEM, 3BEM_FRP, FINN, and GFAS daily area-averaged emission inventories to the eight grids and average absolute bias of $\mathrm{CO}$ (in $\mathrm{kg} \mathrm{m}^{-2}$ ). In the table, the first value indicates the $r$ and the second represents the absolute bias ( $r / b i a s)$. Bold value are not significant ( $p>0.05$ level, Student $t$ test).

\begin{tabular}{lcrr}
\hline & 3BEM_FRP & FINN & GFAS \\
\hline 3BEM_G1 & $0.84 / 933$ & $0.85 / 145$ & $0.82 / 736$ \\
3BEM_FRP_G1 & & $0.67 /-788$ & $0.76 /-197$ \\
FINN_G1 & & & $0.82 / 591$ \\
3BEM_G2 & $0.70 / 436$ & $0.75 / 458$ & $0.79 / 210$ \\
3BEM_FRP_G2 & & $0.61 / 22$ & $0.78 /-226$ \\
FINN_G2 & & & $0.82 /-249$ \\
3BEM_G3 & $0.78 / 1642$ & $0.94 / 1674$ & $0.90 /-136$ \\
3BEM_FRP_G3 & & $0.77 / 32$ & $0.87 /-1778$ \\
FINN_G3 & & & $0.91 /-1811$ \\
3BEM_G4 & $0.81 /-245$ & $0.93 / 996$ & $0.90 /-263$ \\
3BEM_FRP_G4 & & $0.71 / 1241$ & $0.90 /-18$ \\
FINN_G4 & & & $0.88 /-1260$ \\
3BEM_G5 & $\mathbf{0 . 1 6 / - 6 3 4 5}$ & $0.30 /-793$ & $0.36 / 605$ \\
3BEM_FRP_G5 & & $0.47 / 5552$ & $0.84 / 6950$ \\
FINN_G5 & & & $0.80 / 1399$ \\
3BEM_G6 & $0.46 / 12$ & $0.89 / 68$ & $0.88 /-86$ \\
3BEM_FRP_G6 & & $0.32 / 55$ & $0.65 /-99$ \\
FINN_G6 & & & $0.81 /-154$ \\
3BEM_G7 & $0.68 /-14$ & $0.89 / 151$ & $0.85 / 413$ \\
3BEM_FRP_G7 & & $0.60 / 165$ & $0.79 / 427$ \\
FINN_G7 & & & $0.85 / 261$ \\
3BEM_G8 & $0.63 /-138$ & $0.84 /-251$ & $0.79 /-31$ \\
3BEM_FRP_G8 & & $0.65 /-113$ & $0.65 / 106$ \\
FINN_G8 & & & $0.91 / 219$ \\
\hline
\end{tabular}

\subsection{Assessment of fire inventories with AOT}

Figure 6 shows the daily emission estimates from each of the emission inventories used in SAMBBA campaign integrated over the eight grids and the area-averaged values of $\mathrm{AOT}_{550 \mathrm{~nm}}$ for 1 September to 31 October 2012. During the SAMBBA campaign, the grids located in the Arc of Deforestation and in Mato Grosso state exhibited the highest values of averaged $\mathrm{AOT}_{550 \mathrm{~nm}}$. Generally, the inventories that use FRP to estimate the emission of $\mathrm{CO}$ produce similar patterns. Likewise, the emission inventories that utilize the relationship between the burned area, fuel load, and the combustion completeness lead to comparable patterns. This is evident in Fig. 6a, in which 3BEM_FRP and GFAS have lower values during all periods, with daily emission loads of $\mathrm{CO}$ between 20 and $500 \mathrm{~kg} \mathrm{~m}^{-2}$ and an average value of $93 \mathrm{~kg} \mathrm{~m}^{-2}$. In addition, the 3BEM and FINN emission inventories presented a high variability during the analyzed period, with a daily area-averaged $\mathrm{CO}$ emission flux that reaches values greater than $3000 \mathrm{~kg} \mathrm{~m}^{-2}$. The linear correlation coefficient of 3BEM_FRP and GFAS and of 3BEM and FINN are 0.85 and 0.76 , respectively, with a tendency of GFAS
Table 3. Total mean emissions $\left(\mathrm{kg} \mathrm{m}^{-2}\right)$ of $\mathrm{CO}$ in the eight grids shown in Fig. 2.

\begin{tabular}{lrrrr}
\hline \multicolumn{5}{c}{ Total emission of CO $\left(\mathrm{kg} \mathrm{m}^{-2}\right)$} \\
\hline & 3BEM & FINN & GFAS & 3BEM_FRP \\
\hline Grid 1 & 61.660 & 52.971 & 17.485 & 5.636 \\
Grid 2 & 55.234 & 42.631 & 27.706 & 29.059 \\
Grid 3 & 155.346 & 163.552 & 54.891 & 56.815 \\
Grid 4 & 151.720 & 167.518 & 91.905 & 166.423 \\
Grid 5 & 82.271 & 45.945 & 129.866 & 274.896 \\
Grid 6 & 35.199 & 40.412 & 31.118 & 29.811 \\
Grid 7 & 53.072 & 28.266 & 43.981 & 48.541 \\
Grid 8 & 11.342 & 13.252 & 25.674 & 19.633 \\
\hline Total & 605.844 & 554.547 & 422.626 & 630.814 \\
\hline
\end{tabular}

and 3BEM to present higher $\mathrm{CO}$ emission fluxes. In grid 1, the total emission fluxes of CO in 3BEM and FINN from 1 September to 31 October 2012 are, respectively, 61.660 and $52.971 \mathrm{~kg} \mathrm{~m}^{-2}$ (Table 3), an estimation that is $4-10$ times more than GFAS and 3BEM_FRP.

Figure $6 \mathrm{~b}$ shows the area-averaged time series of $\mathrm{CO}$ and $\mathrm{AOT}_{550 \mathrm{~nm}}$ in grid 2, with the four emission inventories showing similar patterns with high emission values on 9 September and between 20 and 30 October 2012. The linear correlation coefficients of 3BEM_FRP and GFAS and of 3BEM and FINN are 0.78 and 0.75 with a tendency of 3BEM $\left(55.234 \mathrm{~kg} \mathrm{~m}^{-2}\right)$ and 3BEM_FRP $\left(29.059 \mathrm{~kg} \mathrm{~m}^{-2}\right)$ to present higher $\mathrm{CO}$ emission fluxes in this region. Also, in the general pattern of temporal evolution, we could observe a good agreement between $\mathrm{CO}$ emission load estimated by the four emission inventories and MODIS $\mathrm{AOT}_{550 \mathrm{~nm}}$. However, the four emission inventories exhibit distinct $\mathrm{CO}$ flux distributions in grid 3 (Fig. 6c). In September, FINN and 3BEM presented higher values than 3BEM_FRP and GFAS during September and October. However, 3BEM_FRP shows higher values than GFAS in September and smaller values in October. The linear correlation coefficients of 3BEM_FRP and GFAS and of 3BEM and FINN are 0.87 and 0.94 , respectively, with a tendency of FINN and 3BEM_FRP to yield higher estimates of the $\mathrm{CO}$ emission flux. The relationship between GFAS and FINN presents a linear correlation coefficient of 0.91. However, the total emission load of CO estimated by FINN ( $\left.163.552 \mathrm{~kg} \mathrm{~m}^{-2}\right)$ is 3 times more than GFAS $\left(54.891 \mathrm{~kg} \mathrm{~m}^{-2}\right)$.

In grid 4, all inventories showed a good agreement with linear correlations coefficients greater than 0.90 . However, during the period from 3 to 10 September, 3BEM_FRP presents six episodes with higher emission loads, which remain undetected in the other inventories (Fig. 6d). The outlier values in 3BEM_FRP are likely to be related to GOES FRP acquisitions, which suggests inconsistencies in GOES data acquisition due to viewing angle and errors in data process- 

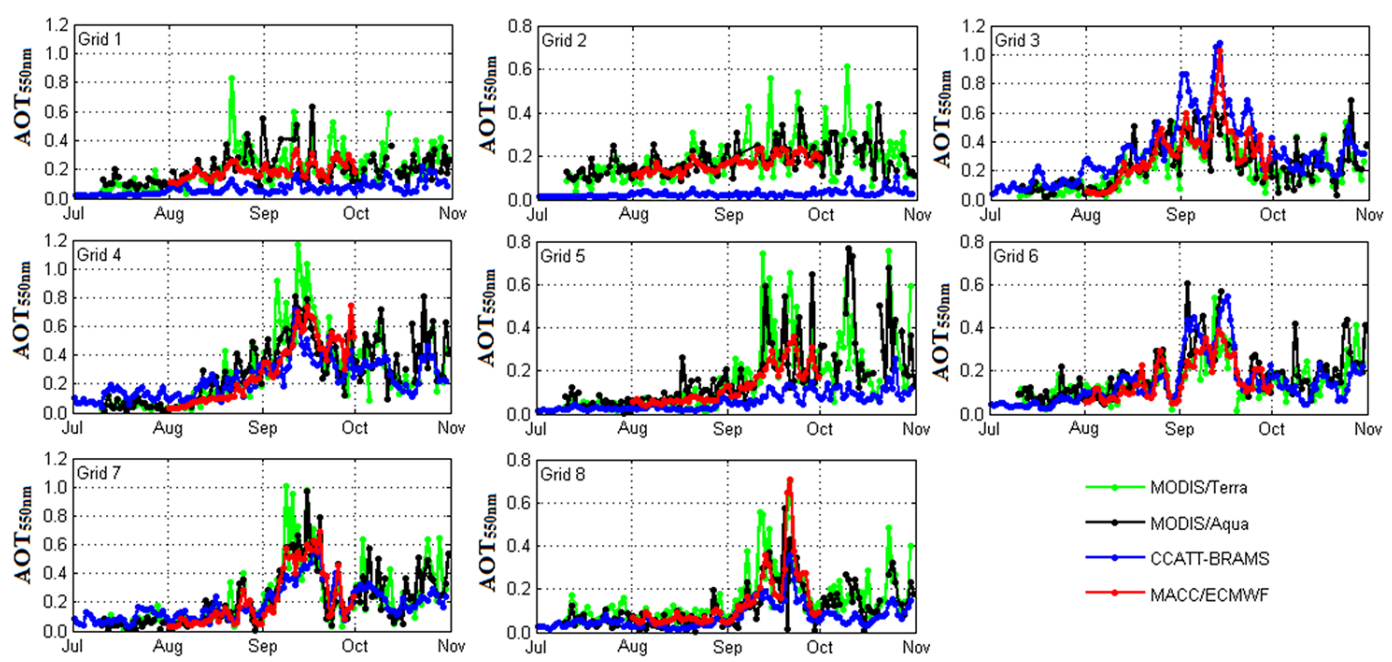

Figure 7. Lat-long average time series of Terra/MODIS AOT $550 \mathrm{~nm}$ (in green), Aqua/MODIS AOT $550 \mathrm{~nm}$ (in black), CCATT-BRAMS simulated $\mathrm{AOT}_{550 \mathrm{~nm}}$ (in blue), and MACC/ECMWF (in red) $\mathrm{AOT}_{550 \mathrm{~nm}}$ analysis. Grids are those shown in Fig. 2.

ing. Grid 5 shows the lowest linear correlation coefficient between the 3BEM and FINN emission inventories during the SAMBBA campaign with 0.30 . In this grid, FINN presents a low estimation of the $\mathrm{CO}$ emission flux when compared with the other emission inventories (as demonstrate in Table 3). Here, FRP-based methods showed larger emissions than the BA-based ones. The 3BEM_FRP model overestimated the emission values by more than $100 \%$ compared to GFAS (Fig. 6e) However, the linear correlation between these emission inventories is 0.84 . In the other grids, the emissions of $\mathrm{CO}$ provided by the four emission inventories show a considerable consistency, with few differences in absolute values, indicating a good agreement across these other regions of South America (Fig. $6 \mathrm{f}-\mathrm{h}$ ).

\subsection{Evaluating the emissions against observations}

During the SAMBBA campaign, operational atmospheric chemistry transport models were applied in real time: (i) the MACC/ECMWF with GFAS and (ii) CCATT-BRAMS with 3BEM. Figure 7 shows the simulated $\mathrm{AOT}_{550 \mathrm{~nm}}$ from MACC/ECMWF (red line), CCATT-BRAMS (blue line), and estimated by Terra (green line) and Aqua (black line) to the eight grid cells. Although 3BEM presents the highest emission flux in grid 1 and grid 2, the CCATT-BRAMS simulation underestimate the MODIS AOT $550 \mathrm{~nm}$. In these grids, the MACC/ECMWF model presents a better consistency with the satellite measurements. One potential reason for the underestimation of CCATT-BRAMS is related to background aerosol unrelated to the fires directly being observed and that is not included in this model, causing low values of simulated $\mathrm{AOT}_{550 \mathrm{~nm}}$ for these grids. Also, MACC/ECMWF assimilates MODIS AOD observations and, even with low emission values in grids 1 and 2, the atmospheric aerosol load is strongly constrained by the MODIS observations.
The assessment of the MACC/ECMWF and CCATTBRAMS models against MODIS AOT $550 \mathrm{~mm}$ reveals a good agreement in terms of the general pattern of the temporal evolution. As shown in the $\mathrm{AOT}_{550 \mathrm{~mm}}$ time series, both methods appear to be able to estimate the influence of aerosols released by fires rather well. However, when the intensity of the biomass burning is too high, the values simulated by MACC/ECMWF and CCATT-BRAMS for the grids 4-8 appear underestimated, possibly due to the influence of smoke on the FRP measurements, lack of fire observations, clouds, aboveground biomass data, or fire size. Moreover, it is possibly to identify an overestimation in grid 3 , mainly due to an out-of-date land use and land cover map that inserts fires over forest areas even if the area had been burned/deforested during earlier years, and a very noticeable underestimation in grid 5, as demonstrated in the inventories.

\section{Conclusions}

Full characterization of the emissions of trace gases and aerosols is often essential for assessing the atmospheric impacts of fire and for constructing fire inventories. These inventories generally rely on data from environmental satellites and provide useful information for weather, climate, and air quality models. In this study, we analyzed data from the four biomass burning emission inventories used during the SAMBBA airborne atmospheric sampling and remote sensing campaign that took place in Rondonia (Brazil) between 1 September and 31 October 2012. Each inventory utilizes distinct methodology, with 3BEM and FINN deriving the emission of trace gases and aerosols through a combination of BA and fuel load metrics based on vegetation maps and field-location-specific coefficients, whilst 3BEM_FRP 
and GFAS estimate biomass burned more directly from FRP measurements made by the EO satellite instruments.

The evaluation of the emission inventories focused on eight pre-defined grid cells (Fig. 2) and demonstrates that inventories that utilize the same methodology, such as 3BEM and FINN on the one hand (BA-based) and GFAS and 3BEM_FRP on the other (FRP-based), show similar patterns in emission spatial distribution, not only in the Arc of Deforestation but also throughout South America. However, they can differ in their absolute values. As such, each inventory has particular characteristics, with 3BEM and FINN showing more emissions of $\mathrm{CO}$ in the Amazon forest logging area, where most of the SAMBBA campaign flights occurred. Furthermore, these emission inventories typically underestimated the smoke loading in the southeastern region of Amazon forest and in the northwestern region of Rondonia, where 3BEM_FRP and GFAS present larger emission fluxes of CO. The best overall linear correlations coefficients were found between 3BEM and FINN, with approximately 0.86, and 3BEM_FRP and GFAS, with approximately 0.85 , which indicate that similar emission methods tend to agree with each other. Furthermore, the comparison of the 3BEM and FINN fire inventories reveal linear correlation coefficients between 0.75 and 0.92 , with larger total emissions of $\mathrm{CO}$ in FINN than in 3BEM for grids 3, 4, 6, and 8.3BEM_FRP and GFAS show linear correlation coefficients between 0.65 and 0.95 , with more emissions of $\mathrm{CO}$ in GFAS than in 3BEM_FRP for grids 1, 6, and 8 .

During the SAMBBA campaign, the assessment of simulated $\mathrm{AOT}_{550 \mathrm{~nm}}$ from MACC/ECMWF and CCATTBRAMS operational atmospheric chemistry transport models with MODIS AOT $_{550 \mathrm{~nm}}$ Terra and Aqua measurements show a good agreement related with general pattern of the time series. Also, MACC/ECMWF and CCATT-BRAMS models are capable of simulating the aerosols released by fires. However, when the intensity of the biomass burning is too high, the aerosol values simulated by the two models underestimate the MODIS measurements.

Acknowledgements. We would like to thank the São Paulo Research Foundation (FAPESP) for their financial support (2012/13575-9) and Minas Gerais State Research Foundation (FAPEMIG, grant number APQ-01698-14). J. W. Kaiser and M. J. Wooster were supported by NERC in the SAMBBA project (grant number NE/J010073/1). The MACC/ECMWF simulations were kindly provided by the precursor of EU's Copernicus Atmosphere Monitoring Service (http://atmosphere.copernicus.eu). The authors thank two anonymous reviewers for useful comments that helped improve the manuscript.

Edited by: H. Coe

\section{References}

Akagi, S. K., Yokelson, R. J., Wiedinmyer, C., Alvarado, M. J., Reid, J. S., Karl, T., Crounse, J. D., and Wennberg, P. O.: Emission factors for open and domestic biomass burning for use in atmospheric models, Atmos. Chem. Phys., 11, 4039-4072, doi:10.5194/acp-11-4039-2011, 2011.

Andreae, M. O. and Merlet, P.: Emission of trace gases and aerosols from biomass burning, Global Biogeochem. Cy., 15, 955-966, 2001.

Andreae, M., Rosenfeld, D., Artaxo, P., Costa, A., Frank, G., Longo, K. M., and Silva Dias, M. A. F.: Smoking rain clouds over the Amazon, Science, 303, 1342-1345, 2004.

Baldassarre, G., Pozzoli, L., Schmidt, C. C., Unal, A., Kindap, T., Menzel, W. P., Whitburn, S., Coheur, P.-F., Kavgaci, A., and Kaiser, J. W.: Using SEVIRI fire observations to drive smoke plumes in the CMAQ air quality model: a case study over Antalya in 2008, Atmos. Chem. Phys., 15, 8539-8558, doi:10.5194/acp-15-8539-2015, 2015.

Bowman, D. M. J. S., Balch, J. K., Artaxo, P., Bond, W. J., Carlson, J. M., Cochrane, M. A., D’Antonio, C. M., DeFries, R. S., Doyle, J. C., Harrison, S. P., Johnston, F. H., Keeley, J. E., Krawchuk, M. A., Kull, C. A., Marston, J. B., Moritz, M. A., Prentice, I. C., Roos, C. I., Scott, A. C., Swetnam, T. W., van der Werf, G. R., and Pyne, S. J.: Fire in the Earth System, Science, 324, 481-484, 2009.

Bustamante, M. M. C., Roitman, I., Aide, T. M., Alencar, A., Anderson, L., Aragão, L., Asner, G. P., Barlow, J., Berenguer, E., Chambers, J., Costa, M. H., Fanin, T., Ferreira, L. G., Ferreira, J. N., Keller, M., Magnusson, W. E., Morales, L., Morton, D., Ometto, J. P. H. B., Palace, M., Peres, C., Silvério, D., Trumbore, S., and Vieira, I. C. G.: Towards an integrated monitoring framework to assess the effects of tropical forest degradation and recovery on carbon stocks and biodiversity, Glob. Change Biol., 1, 92-109, doi:10.1111/gcb.13087, 2016.

Cardozo, F. S., Pereira, G., Shimabukuro, Y. E., and Moraes, E. C.: Analysis and Assessment of the Spatial and Temporal Distribution of Burned Areas in the Amazon Forest, Remote Sens., 6, 8002-8025, 2014

Chuvieco, E., Cocero, D., Riano, D., Martinc, P., Martínez-Vegac, J., Rivad, J., and Pérez, F.: Combining NDVI and surface temperature for the estimation of live fuel moisture content in forest fire danger rating, Remote Sens. Environ., 92, 322-331, 2004.

Christian, T. J., Kleiss, B., Yokelson, R. J., Holzinger, R., Crutzen, P. J., Hao, W. M., Saharjo, B. H., and Ward, D. E.: Comprehensive laboratory measurements of biomass-burning emissions: 1. Emissions from Indonesian, African, and other fuels, J. Geophys. Res., 108, 4719, doi:10.1029/2003JD003704, 2003.

Crutzen, P. J. and Andreae, M. O.: Biomass burning in the tropics: Impact on atmospheric chemistry and biogeochemical cycles, Science, 250, 1669-1678, 1990.

De Santis, A., Asner, G. P., Vaughan, P. J., and Knapp, D. E.: Mapping burn severity and burning efficiency in California using simulation models and Landsat imagery, Remote Sens. Environ., 114, 1535-1545, doi:10.1016/j.rse.2010.02.008, 2010.

Efron, B.: The jackknife, the bootstrap, and other resampling plans, Society of Industrial and Applied Mathematics, CBMS-NSF Monographs, No. 38, Philadelphia, PA, 1982. 
Ellicott, E., Vermote, E., Giglio, L., and Roberts, G.: Estimating biomass consumed from fire using MODIS FRE, Geophys. Res. Lett., 36, L13401, doi:10.1029/2009GL038581, 2009.

Fearnside, P. M.: Global warming and tropical land use change: Greenhouse gas emissions from biomass burning, decomposition and soils in forest conversion, shifting cultivation and secondary vegetation, Climatic Change, 46, 115-158, 2000.

Freeborn, P. H., Wooster, M. J., and Roberts, G.: Addressing the spatiotemporal sampling design of MODIS to provide estimates of the fire radiative energy emitted from Africa, Remote Sens. Environ, 115, 475-498, 2011.

Giglio, L., van der Werf, G. R., Randerson, J. T., Collatz, G. J., and Kasibhatla, P.: Global estimation of burned area using MODIS active fire observations, Atmos. Chem. Phys., 6, 957974, doi:10.5194/acp-6-957-2006, 2006.

Giglio, L., Randerson, J. T., van der Werf, G. R., Kasibhatla, P. S., Collatz, G. J., Morton, D. C., and DeFries, R. S.: Assessing variability and long-term trends in burned area by merging multiple satellite fire products, Biogeosciences, 7, 1171-1186, doi:10.5194/bg-7-1171-2010, 2010.

Heil, A., Kaiser, J. W., van der Werf, G. R., Wooster, M. J., Schultz, M. G., and Dernier van der Gon, H.: Assessment of the real-time fire emissions (GFASv0) by MACC, Tech. Memo. 628, ECMWF, Reading, UK, 2010.

Houghton, R. A., Lawrence, K. T., Hackler, J. L., and Brown, S.: The spatial distribution of forest biomass in the Brazilian Amazon: A comparison of estimates, Glob. Change Biol., 7, 731-746, 2001.

Ichoku, C. and Kaufman, Y. J.: A method to derive smoke emission rates from MODIS fire radiative energy measurements, IEEE T. Geosci. Remote Sens., 43, 2636-2649, 2005.

Justice, C. O., Giglio, B., Korontzi, S., Owens, J., Morisette, J. T., Roy, D. P., Descloitres, J., Alleaume, S., Petitcolin, F., and Kaufman, Y.: The MODIS fire products, Remote Sens. Environ, 83, 244-262, 2002.

Kaiser, J. W., Suttie, M., Flemming, J., Morcrette, J.-J., Boucher, O., and Schultz, M. G.: Global real-time fire emission estimates based on space-borne fire radiative power observations, AIP Conf. Proc., 1100, 645-648, 2009.

Kaiser, J. W., Heil, A., Andreae, M. O., Benedetti, A., Chubarova, N., Jones, L., Morcrette, J.-J., Razinger, M., Schultz, M. G., Suttie, M., and van der Werf, G. R.: Biomass burning emissions estimated with a global fire assimilation system based on observed fire radiative power, Biogeosciences, 9, 527-554, doi:10.5194/bg-9-527-2012, 2012.

Kaufman, J. B., Cummings, D. L., Ward, D. E., and Babbitt, R.: Fire in the Brazilian Amazon: Biomass, nutrient pools, and losses in slashed primary forests, Oecologia, 104, 397-408, 1995.

Kaufman, Y. J. and Tanré, D.: Algorithm for Remote Sensing of Tropospheric Aerosols from MODIS, MODIS Algorithm Theoretical Basis Document, Product ID: MOD04, revised 26 October 1998, available at: http://modis.gsfc.nasa.gov/data/atbd/ atbd_mod02.pdf (last access: 30 October 2015), 1998.

Kumar, S. S., Roy, D. P., Boschetti, L., and Kremens, R.: Exploiting the power law distribution properties of satellite fire radiative power retrievals: A method to estimate fire radiative energy and biomass burned from sparse satellite observations, J. Geophys. Res., 116, D19303, doi:10.1029/2011JD015676, 2011.
Longo, K. M., Freitas, S. R., Andreae, M. O., Setzer, A., Prins, E., and Artaxo, P.: The Coupled Aerosol and Tracer Transport model to the Brazilian developments on the Regional Atmospheric Modeling System (CATT-BRAMS) - Part 2: Model sensitivity to the biomass burning inventories, Atmos. Chem. Phys., 10, 5785-5795, doi:10.5194/acp-10-5785-2010, 2010.

Mao, Y. H., Li, Q. B., Chen, D., Zhang, L., Hao, W.-M., and Liou, K.-N.: Top-down estimates of biomass burning emissions of black carbon in the Western United States, Atmos. Chem. Phys., 14, 7195-7211, doi:10.5194/acp-14-7195-2014, 2014.

Olson, J. S., Watts, J. A., and Allison, L. J.: Major world ecosystem complexes ranked by carbon in live vegetation: A database, available at: http://cdiac.esd.ornl.gov/ndps/ndp017.html (last access: 7 August 2010), 2000.

Pereira, G., Freitas, S. R., Moraes, E. C., Ferreira, N. J., Shimabukuro, Y. E., Rao, V. B., and Longo, K. M.: Estimating trace gas and aerosol emissions over South America: Relationship between fire radiative energy released and aerosol optical depth observations, Atmos. Environ., 43, 6388-6397, 2009.

Peterson, D., Wang, J., Ichoku, C., Hyer, E., and Ambrosia, V.: A sub-pixel-based calculation of fire radiative power from MODIS observations: 1: Algorithm development and initial assessment, Remote Sens. Environ., 129, 262-279, doi:10.1016/j.rse.2012.10.036, 2012.

Prins, E. M., Felz, J. M., Menzel, W. P., and Ward, D. E.: An overview of GOES-8 diurnal fire and smoke results for SCAR-B and 1995 fire season in South America, J. Geophys. Res., 103, 31821-31825, 1998.

Randerson, J. T., Chen, Y., van der Werf, G. R., Rogers, B. M., and Morton, D. C.: Global burned area and biomass burning emissions from small fires, J. Geophys. Res., 117, G04012, doi:10.1029/2012JG002128, 2012.

Roberts, G., Wooster, M. J., Perry, G. L. W., Drake, N., Rebelo, L. M., and Dipotso, F.: Retrieval of biomass combustion rates and totals from fire radiative power observations: Application to southern Africa using geostationary SEVIRI imagery, J. Geophys. Res.-Atmos., 110, D21111, doi:10.1029/2005JD006018, 2005.

Rosário, N. E., Longo, K. M., Freitas, S. R., Yamasoe, M. A., and Fonseca, R. M.: Modeling the South American regional smoke plume: aerosol optical depth variability and surface shortwave flux perturbation, Atmos. Chem. Phys., 13, 2923-2938, doi:10.5194/acp-13-2923-2013, 2013.

Schroeder, W., Csiszar, I., and Morisette, J.: Quantifying the impact of cloud obscuration on remote sensing of active fires in the Brazilian Amazon, Remote Sens. Environ., 112, 456-470, 2008.

Seiler, W. and Crutzen, P. J.: Estimates of gross and net fluxes of carbon between the biosphere and atmosphere from biomass burning, Climatic Change, 2, 207-247, 1980.

Sestini, M., Reimer, E., Valeriano, D., Alvalá, R., Mello, E., Chan, C., and Nobre, C.: Mapa de cobertura da terra da Amazônia legal para uso em modelos meteorológicos, in: Simpósio Brasileiro de Sensoriamento Remoto (SBSR), 11, Belo Horizonte, Anais, São José dos Campos: INPE, 2003, Artigos, 2901-2906, CD-ROM, On-line, ISBN 85-17-00018-8, 2003.

Setzer, A. W., Pereira Jr., A. C., and Pereira, M. C.: Satellite studies of biomass burning in Amazonia: some practical aspects, Remote Sens. Rev., 10, 91-103, 1994. 
Shimabukuro, Y. E., Pereira, G., Cardozo, F. S., Stockler, R., Freitas, S. R., and Coura, S. M. C.: Biomass burning emission estimation in Amazon tropical forest, in: Domingo Alcaraz Segura; Carlos Marcelo Di Bella; Julieta Veronica Straschnoy (Org.), Earth Observation of Ecosystem Services, 1st Edn., Oxford, UK, Taylor \& Francis, 1, 112-130, 2013.

Val Martin, M., Logan, J. A., Kahn, R. A., Leung, F.-Y., Nelson, D. L., and Diner, D. J.: Smoke injection heights from fires in North America: analysis of 5 years of satellite observations, Atmos. Chem. Phys., 10, 1491-1510, doi:10.5194/acp-10-14912010, 2010.

van der Werf, G. R., Randerson, J. T., Giglio, L., Collatz, G. J., Mu, M., Kasibhatla, P. S., Morton, D. C., DeFries, R. S., Jin, Y., and van Leeuwen, T. T.: Global fire emissions and the contribution of deforestation, savanna, forest, agricultural, and peat fires (19972009), Atmos. Chem. Phys., 10, 11707-11735, doi:10.5194/acp10-11707-2010, 2010.

Vermote, E., Ellicott, E., Dubovik, O., Lapyonok, T., Chin, M., Giglio, L., and Roberts, G. J.: An approach to estimate global biomass burning emissions of organic and black carbon from MODIS fire radiative power, J. Geophys. Res., 114, 205-227, 2009.
Wiedinmyer, C., Akagi, S. K., Yokelson, R. J., Emmons, L. K., AlSaadi, J. A., Orlando, J. J., and Soja, A. J.: The Fire INventory from NCAR (FINN): a high resolution global model to estimate the emissions from open burning, Geosci. Model Dev., 4, 625641, doi:10.5194/gmd-4-625-2011, 2011.

Wooster, M. J., Zhukov, B., and Oertel, D.: Fire radiative energy for quantitative study of biomass burning: Derivation from the BIRD experimental satellite and comparison to MODIS fire products, Remote Sens. Environ, 86, 83-107, 2003.

Wooster, M. J., Roberts, G., and Perry, G. L. W.: Retrieval of biomass combustion rates and totals from fire radiative power observations: Calibration relationships between biomass consumption and fire radiative energy release, J. Geophys. Res., 110, D24311, doi:10.1029/2005JD006318, 2005.

Xu, W., Wooster, M., Roberts, G., and Freeborn, P.: New GOES imager algorithms for cloud and active fire detection and fire radiative power assessment across North, South and Central America, Remote Sens. Environ., 114, 1876-1895, 2010.

Yebra, M., Chuvieco, E., and Riano, D.: Estimation of live fuel moisture content from MODIS images for fire risk assessment, Agr. Forest Meteorol., 148, 523-536, 2009. 